\title{
RELIGION, POSTMODERNISM AND POSTMODERN SCHOLARSHIP IN AFRICA
}

\author{
Jacob Olu ADETOLU, MA \\ Department of Religious Studies \\ Obafemi Awolowo University Ile-Ife
}

\begin{abstract}
There is a somewhat agreement among the world academia and intellectuals that the world has moved beyond the stipulated margins of modernism into what is called the postmodern era. Consequently, postmodernism as a school of thought has become a subject of scholastic discourse among its protagonists and antagonists. What is done in this paper is an appraisal of postmodernism in a broader sense and specifically postmodern scholarship in the discipline of Religious Studies in Africa. The paper is divided into three sections: The first section examines the postmodernism project; the second focuses on the spirit of postmodernism within the academic study of religion with special interest in Africa, while the third section concludes the paper by examining some criticisms against postmodernism.
\end{abstract}

Keywords: Postmodernism, Deconstruction, Post-structuralism, Decolonization and Modernism

\section{Introduction}

The academic discipline of religion has had a long history of scholastic groundbreaking discoveries encapsulated in the works of certain figures that have been accorded the privilege position of ancestors as far as the academic study of religion is concerned. Durkheim's discourse on the nature of the sacred, Weber's Verstehenden methodology, Malinowski's exploration of the distinctions between religion and common sense and Freud's parallel between religious personal rituals and collective ones represent some of the foundational discourses that constitute the root of academic study of religion and as well remain reference points for contemporary Religious Studies scholars (GEERTZ 1973, 88). One important issue that must be noted in this regard is that, virtually all of these ground-breaking discoveries by these ancestors were made during the modern era and within scholastic framework and positivist frame of mind provided by, and characteristic of modern western thought (KUNIN 2006, 24).

Postmodernism as a scholastic phenomenon could be taken as a child of philosophical temperament. This assertion is compatible with the fact that Philosophy is about the only discipline that asks critical question about its validity as a subject of enquiry. Philosophy usually questions its method, its claim of its ability or competence to handle the task it sets before itself. These 
philosophic dispositions are unconnected with the fact that, it is the nature of philosophy to ask fundamental questions. In answering these questions, nothing is accepted at its face value. Consequently, issues of whatever kind hardly get resolved in Philosophy.

The age of enlightenment and the modern era have brought about some level of consensus in the humans' quest to configure the nature of their being, their existence and of their natural environment and other phenomena with which the human existence are inevitably interwoven. Moreover, human progress and advancements expressed chiefly by the industrial revolution and technological innovations seem to have suggested that, there can be some objective truth and knowledge that could be granted consensus privilege as far as the humans' quest to know and to resolve his conflict is concerned. Indeed, the modern era has recorded some progress in the evolution of universal consensus in the scientific disciplines as well as in the humanities.

The dawn of the twentieth century seems to have reawakened philosophical temperaments that began to question discourses across disciplines which have reached varying levels of consensus in the human quest for knowledge. This is the origin of what has been termed "postmodernism" of which according to Lyotard, as discussed by Gary Aylesworth, its main goal is the rejection of the notion that inter-subjective communication implies a set of rules already agreed upon, and that universal consensus is the ultimate goal of discourse (GARY 2013, 21).

The aim of this paper is to appraise postmodernism and postmodern scholarship in Africa. This will be done in three parts. The first part will examine the postmodernism project; the second part will focus on the spirit of postmodernism within the academic study of religion with special interest on Africa. The third part, which concludes the paper examines some criticisms against postmodernism.

\section{The Postmodernism Project}

Two eras could be said to have preceded the postmodern era, the premodern and the modern. Premodernism, which originally means "possessed by authority" (for example, the religious authority of Catholic Church) was an age in which the individual was dominated by tradition (MORLEY 2013, Web. N. P.). Modernism on the other hand was birthed by the enlightenment-humanist rejection of tradition and authority in favor of reason and natural science, grounded upon the assumption of the autonomous individual, as the sole source of meaning and truth within a linear conception of history of a "real" world that becomes increasingly real and objectified (MORLEY 2013, Web. N. P.). Postmodernism can therefore be taken as a philosophical efforts targeted at examining the nature of meaning, knowing, and of knowledge in general even though academics in many fields 
have debated over its precise definition. Postmodernists moreover question the validity of the faith in science and rationalism that originated during the Enlightenment and that became associated with the philosophy known as modernism.

The postmodern "boundary" is not so much of the period it begins, but more of the body of discourses that separate it from the modern era. It has been observed that postmodernism is so diffuse to an extent that its plural form 'postmodernisms' would be much more correct in referring to it. Thus, it is its somewhat fluidity and open-ended nature that makes it an epistemological model - the quality that makes it pretty difficult to define (DOLAN-HENDERSON 1996, 217). However, postmodernism has been conceived as a reaction, and perhaps a protest against the naïve and earnest trust and confidence in progress, and against the modern celebration and confidence in objective or scientific truth and advancement. Specifically in philosophy, postmodernism "implies a mistrust of the grand récits of modernity" (DOLAN-HENDERSON 1996, 217).

From the above, the postmodernism project is in its very essence, involves the scrutinization and a somewhat rejection of the claim of modernity embedded more or less in the justification of Western society and confidence in progress encapsulated in the thoughts and writings of philosophical figures such as Kant, Hegel, Marx etc., all arising from utopians visions of perfection achieved through evolution, social progress, education and the deployment of science (DOLAN-HENDERSON 1996, 295) Postmodernism as a term first entered the philosophical lexicon in 1979, with the publication of [The Postmodern Condition] by Jean-François Lyotard (GARY 2013, 1). One of the core points in Lyotard's postmodern discourse is his rejection of totalising perspective on history and society, and what he referred to as historical grand narrative exemplified in Marxism with its attempt to explain the world in terms of patterned interrelationship (AGGER 1991, 116). In this regard, Agger opines that Lyotard's postmodern discourse is a clear and express rejection of Marxist totalizing tendencies and of its political radicalism, maintaining that, it is not possible for one to narrate a large story about the world, but a small one from a heterogeneous point of view of a subject position (AGGER 1991, 116).

The insistence of Foucault that knowledge must not be taken to be a phenomenon that must necessarily be accorded a privilege of unanimity, but that, it must rather be traced to diverse and different practices and discourses within the framework of which such body of knowledge are formulated is in line with the view of Lyotard discussed above, and as well spelt out the goal of the postmodern scholastic tradition. What the view of Foucault here suggests as stated by Beatrice Skordili is that, there is no such thing as universal truth, thus, Foucault rejects the existence of universal truth altogether (SKORDILI 2001, 337). Moreover, Foucault's postmodern discourse on phenomena such as 
criminality, sexuality and medicine emphasizes the idea of de-subjectification in which sociologically speaking, the "death of the subject" will give room for a critical interpretation of theories by the reader, and will also enable the survey subject to become an active participant in the research (SKORDILI 2001, 337).

There are other categories of discourse that scholars usually encounter difficulty in finely distinguishing from postmodernism. In this regard, poststructuralism and deconstruction readily come to the fore. Be that as it may, Agger opines that, there is a serious overlap between post-structuralism and postmodernism. Consequently, under the influence of Derrida and some French Feminists such as Kristeva, Agger takes post-structuralism to be a theory of knowledge and language, while following the tradition of scholars such as Lyotard, Foucault, Barthes etc., he conceives postmodernism as a theory of society, culture and history (AGGER 1991, 112). Derrida, one of the chief exponents of post-structuralism, is said to be responsible for the coinage of the term "deconstruction" which in essence means a philosophical method of looking for weak points in modern thinking and established ways of perception (1991, 216). In sum, these three different categories of discourse, (postmodernism, poststructuralism and deconstruction) irrespective of whether scholars agreed on their differences or not, one thing that is without dispute is that, they are all critical response to modern scholarship.

Although, this essay is about religion and postmodern scholarship in Africa, it is expedient we take a look at the manifestation of the postmodern temperament in the academic study of religion in general. Friedrich Nietzsche was a scholar whose style of thinking and writing mostly expressed in his skepticism about the notions of truth and fact anticipated some of the central tenets of postmodernism, such as the aesthetic attitude towards the world that sees it as a 'text', the denial of facts and essences, the celebration of the plurality of interpretations and the fragmented self, the politicization of discourse and the downgrading of reason (BLACKBURN 1996, 262). Nietzschean skepticism reached its peak by his pronouncement that "God is dead", a pronouncement that has attracted serious responses and attentions from various theologians. To some extent, such attentions and responses have constituted the bulk of postmodern discourse in the academic field of religion.

Thomas J. J. Altizer, a theologian, interpreted the Nietzschean pronouncement that "God is dead" as the fullest realisation of the original, but forgotten message of Jesus that the kingdom of God is present in the "here and now." (CARLSON 2001, 11). In Altizer's view as stated by Carlson, the postulation of God's death is compatible with, and just as it reinforces the theist belief in the classical transcendent and eternal God who remains beyond this world and its history (CARLSON 2001, 11). It is through the death of God that he was able to fully and irreversibly enter into the human historical world, 
thereby liberating mankind from his guilty consciousness. According to Carlson, Altizer's reading and understanding of Nietzche is within the framework of "Hegelian conception of kenosis and incarnation: the negation of God's other worldly transcendence occurs in the self-emptying through which God becomes fully incarnated and thus immanent in this world and its history" (CARLSON 2001, 11).

Another prominent scholastic discourse of postmodernism within the academic discipline of religion is found in the area of feminism and ecofeminism. Susan Dolan-Henderson in this regard has identified the three moments of postmodernism. It is necessary that the first two moments should be discussed so that the understanding of how feminism is intricately entrenched in postmodernism can be brought to limelight. The first moment according to her is the postmodern critique of modernity which "consists in unmasking modernity's contradictory impulses and results" (DOLAN-HENDERSON 1996, 217). In relation to this, modernity was discovered to have failed to deliver its avowed goals and objectives. Instead of bringing to fulfillment its promises: freedom, equality and unlimited progress, what it produced were "genocide, ecological disaster, and multiple forms of oppression, particularly of indigenous populations and women" (DOLAN-HENDERSON 1996, 217). The second moment in postmodernism as identified by Dolan-Henderson is the attack of the autonomous self by the postmodernists in which the postmodernists seek the "disappearance of the subject"- the autonomous self of enlightenment which centered meaning in itself, with its belief in its unlimited power and freedom which has since remained elusive, thereby giving room for a shift from the subject to a communal forms of meaning (DOLAN-HENDERSON 1996, 217). This shift from subjectivity to a communal forms of meaning is significant for the feminists in some number of ways; first, it provides the basis for the questioning of feminine and masculine categories; second, a proper meaning for the term "woman" or "womanhood" becomes problematic and uncertain; and lastly, there is the possibility of an interrogation of the hitherto patriarchally produced sexual meanings (DOLAN-HENDERSON 1996, 217). Solan-Henderson moreover noted that, the fact that postmodernism called into question the "enlightenment project has enabled feminist theologians to interrogate the male bias of even the so-called liberal theologies" $(1996,217)$. All of the above attributes of postmodernism in relation to feminism remains fundamental issues that continue to give critical supports to contemporary feminists ideologies.

\section{Religion and Postmodern Scholarship in Africa}

The postmodern scholastic tradition has infiltrated itself into virtually all forms of academic disciplines, the field of Religious Studies inclusive. Postmodernism as an academic temperament may not be as much pronounced in other disciplines 
as it is in the field of Philosophy. Nevertheless, there are variants of scholastic engagements in some of these disciplines reminiscent of the postmodernist questioning of grand récits of modernity and of the established body of knowledge across these disciplines.

One scholar that has demonstrated this scholastic disposition in the field of Religious Studies is Clifford Geertz. In his investigation of religion as a cultural system, Geertz opines that the anthropological work on religion accomplished since the Second World War, when placed side by side with the one accomplished just before and just after the first reveals two important shortcomings: First, the latter has made no theoretical advances over the former. Second, it has drawn what concepts it used from a narrowly defined intellectual tradition $(1973,87)$. Geertz's observation in this regard, even though could not be said to portray an explicit postmodern tendency, but still nevertheless remains significant in that it pointed out a sharp distinction between two specified scholastic epochs as far as academic study of religion is concerned. Geertz, moreover laments the stagnation besetting the anthropological study of religion in his day, blaming it on the production of minor variations on classical theoretical themes $(1973,88)$. According to Geertz, the scholastic disposition within the academic study of religion that favors what he refers to as "the solemn reduplication of the achievements of accepted masters" such as Durkheim, Weber, Freud, Malinowski etc. is the scholastic malady that has been parochializing the thought of contemporary religious scholars $(1973,88)$. A position of this nature is reminiscent of the postmodern scholarship that seeks to critique and transcend the limitation brought about by modernism and modernist scholars.

If there is any Continent that is in urgent need of scholastic enterprise with which to transcend the limitation brought about by modernism, that Continent undoubtedly would be the African Continent. This opinion is strongly connected with the widely held belief among the African academia that the contemporary problems facing the Continent are deeply entrenched in western and Eurocentric ideas of modernism and colonialism. In this regard, most contemporary scholars and thinkers of African descent are becoming the more conscious of the danger of modernity and the need to embark on an urgent decolonization of African scholarship and the deconstruction of certain western paradigms clothed in the gap of Universal consensus that seems to inevitably subjugate Africa perpetually under western control. In other, words, the view as shared and expressed by some of these scholars is that, African scholars and thinkers need to deconstruct certain western and Eurocentric configurations of certain aspect of humanity for her to break away from the shackles of underdevelopment. To some degree, this has become noticeable across the various disciplines of humanity in recent time just as some of these scholars have 
being demonstrating varying degree of skepticism and a general critique of western institutions and knowledge.

For instance, Sam Aluko, in his attempt to chart a new direction towards the development of Africa's economy bemoans foreign economic theories imported from the West and the quest to implement them wholly without adapting to certain modifications that reflect the peculiarity of the African experience $(2007,85)$. Noting particularly that economic theories that enhanced and sustained economic development in Europe and America failed to do the same in Africa, Aluko remarks:

There are no universal economic dogmas applicable at all times, to all places, and to all economies irrespective of their respective stages of development. Therefore, the African economists, operating in an immature economy, must question the eternal and universal validity of the existing economic theories. $(2007,87)$

In a style and manner reminiscence of postmodern frame of mind, notable African scholars have also embarked on the deconstruction and the decolonization of western epistemological and institutional paradigms in the area of culture and religion. In his essay entitled: "Rethinking Humanities Scholarship in Africa", Olatunji Oloruntimehin among other issues, bemoans the essence and implication of globalization on the Continent of Africa with its uniformizing socio-economic policies being imposed from outside by dominant powers in the process of global governance and the consequent distortion of the civic order and cultural values of developing countries $(2007,7)$. As expressed in the view of Oloruntimehin, there are certain phenomena that make globalization a dangerous phenomenon for the African Continent: First, there is a high level of ignorance on the side of African political leaders and elites that globalization is "in essence the apogee of the long process of the westernization of the world, and the implied control of resources by a few powers, which earlier manifested in various forms of imperialism" $(2007,6)$. Second, there is the place and role that have been ascribed to science and technology in the on-going globalization process. In support of these opinions, Oloruntimehin, citing Dennis Laurence Cuddy opines that "science and capitalism are the two forces of contemporary society; that science and technology has effectively taken control of the material world, while capitalism has effectively structured it" $(2007,6)$. If one considers the above two points, it would be discovered that both re-enforces one another to plunder Africa socio-economically. From all indications, Africa does not yet have the scientific and the technological wherewithal for heavy industrialization and the production of certain goods in a massive manner that would make her to become major player in the new global free-market economy. Thus, according to Martin Khor, 
Africa has been experiencing an upsurge in inequalities of wealth and opportunities arising from globalization and her socio-cultural conditions have been made worse by the workings of the globalized free-market economy (2000, $1)$.

The way out of this menace as far as Africa is concerned calls for a rudimentary and fundamental approaches and changes. This will enable Africa to "cultivate knowledge of her cultural heritage, and on the basis of her understanding of her own identity project herself and her distinctive cultures upon other cultures of the world" (Oloruntimehin 2007, 13). To achieve this objective, academia in Africa needs to imbibe the postmodern scholastic frame of mind to do a rethinking and the decolonization of the existing body of knowledge that would bequeath real socio-cultural and politico-economic freedom to Africa.

The quest to reconfigure Africa's intellectual enterprise in order to project and elevate her true identity free from the colonial project of the modern era to a postmodern African identity that can place her at par with her western counterpart is not restricted to only socio-economic and political issues alone. There has been awareness on the side of notable African Religious Studies scholars and Theologians of the need to decolonize and deconstruct the body of knowledge bequeathed to Africa through colonialism if the discipline of Religious Studies is to become the more relevant in addressing the peculiarity of the African religious space highly embellished with the believe in the activities of spirits and spiritual forces and other malevolent powers capable of inflicting pain or favor on human beings. To this end, there has been what has been termed the Theology of Decolonization. A. O. Nkwoka while quoting D. Wa Said defined the Theology of Decolonization as "the scientific enterprise of which the main purpose is the liberation of the wretched of the third world from spiritual-sociopolitico-economic colonialism, imperialism and neocolonialism" (2007,227).

The need to decolonize the discipline of Religious Studies in general and Biblical Studies in particular is summarily put together by Nkwoka thus: "the development of 'a living theology' is indicative of the fact that Western theology is not alive to the needs of the African theological enterprise" $(2007,229)$. The abnormality that characterized the Western style of the study of religion according to Nkwoka is that religion is approached, not as a faith, but as social phenomenon. Thus, for him, any religion that ceases to be faith has lost its essence as a religion, because it is the faith and spirituality of a religion that makes it an essential social phenomenon $(2007,228)$. This idea with which religion is viewed as a pure social phenomenon comes from Euro-American thinking resulting in what Nkwoka described as "a perspective of leaving the substance and chasing the shadow" which is a feature of post-Christian society in which the advancements in science and technology have made religion a societal nuisance $(2007,228)$. 
It is on the basis of the above that some African Religious Studies Scholars and Theologians in post-colonial and postmodern era are advocating the restructuring of the curriculum of Religious Studies Departments in Nigerian universities and the restructuring of the curriculum of theological schools to provide for "Africanized" theology. The African world of spirit-forces has been opined to share some affinity with the Palestinian world of the Bible. Thus, Religious Studies in general and biblical scholarship in particular should lay more emphasis on the spiritual side of theology rather than the intellectual and the biblical sciences which disparage the Bible and makes it irrelevant to the religious worldview and the lived experiences of the Africans (NKWOKA 2007, 234).

\section{Conclusion}

So far, we have been able to discuss the phenomenon of postmodernism as an offshoot of philosophical temperament by which notable claims and achievements of modernity have been questioned and challenged. It has also been discussed that postmodernism as a scholastic endeavor has infiltrated itself into all aspects of human disciplines and intellectual enterprise. Here in the Continent of Africa, scholars in the disciplines of humanity poised with the postmodern frame of mind have been engaging in the deconstruction of existing texts and literatures and the decolonization of the existing body of knowledge bequeathed to Africa through the instrumentality of colonialisms with which Africa has been relegated to the level of an inferior race, in comparison to which her western counterpart has be deemed superior. Be this as it may, one could assert that the scholastic rivalry between modernist and postmodernist is totally uncalled for. The view and the criticism of Jurgen Habermas as discussed below will suffice to explain our point.

Habermas as discussed by Gary is regarded by most scholars as the most prominent voice in critiquing postmodernism (GARY 2013, 20). The criticisms of Habermas as stated by Gary against postmodernism are not directed towards the postmodernist argumentative attack against the subject or the autonomous self of the modern era. His critical attack against postmodernism is more towards society and societal communicative actions (GARY 2013, 20). For instance, Habermas, according to Gary, strategically put up, and defended argumentative reasons that center on inter-subjective communication against the experimental and avant-garde strategies of postmodernist scholars such as Nietzsche, Derrida and Foucault etc., (GARY 2013, 20). The core argument of Habermas against these scholars is entrenched in his claims that they all "commit a performative contradiction in their critiques of modernism by employing concepts and methods that only modern reason can provide" (GARY 2013, 20). Thus, as it has been noted already, the modernist and postmodernist scholastic 
dichotomy is totally uncalled for. What is needed by the human race is progress, and it is without doubt that modernism has helped human community all over the world in this regard. However, as the postmodernists are apt to point out, modernism is replete with a lot of problems and contradictions. Nevertheless, the postmodernists must also be reminded that without modernism, there cannot be postmodernism. Postmodernism arose as scholastic quest to give a critical appraisal to the modern era. Just as pointed out by Habermas, postmodernists all along have been making use of the concepts and methods formulated by modern scholars (GARY 2013, 20)." This is a sufficient ground to create a truce between the two scholastic epochs and traditions. And this truce must first recognize the African condition.

\section{Relevant Literature}

1. AGGER, Ben. "Critical Theory, Poststructuralism, Postmodernism: Their Sociological Relevance", [Annual Review of Sociology], pp105-131, 1991. Vol. 17, Retrieved, July 2013. Web.

2. ALUKO, Sam. "New Directions on Scholarship in Economics in Africa," [Rethinking the Humanities in Africa, SOLA Akinrinade et al Eds.], pp79-114, 2007. Obafemi Awolowo University Press: IleIfe. Paperback.

3. GARY, Aylesworth, "Postmodernism", [The Stanford Encyclopedia of Philosophy, Edward N. Zalta Ed.], N. P. September 2005. Web.

4. BLACKBURN, Simon. [Oxford Dictionary of Philosophy], 1996. Oxford University Press: New York and Oxford. Paperback.

5. CARLSON, Tom. "Altizer, Thomas J. J.", [Encyclopedia of Postmodernism, VICTOR E. Taylor and CHARLES E. Winquist Eds.], pp10-11, 2001. Routledge: London and New York. E-book. 
6. DERRIDA, Jacques. "Deconstruction," [A Dictionary of Literary Terms and Literary Theory, J. A. Cuddon Ed., $3^{\text {rd }}$ edn.], Blackwell: London. Paperback.

7. DOLAN-HENDERSON, Susan. "Postmodernism," [Dictionary of Feminist Theologies, LETTY M. Russell and SHANNON J. Clarkson Eds.], pp217-218, 1996. Westminster John Knox Press: Kentucky. Paperback.

8. GEERTZ, Clifford. [The Interpretation of Cultures: Selected Essays], 1973. Basicbooks: New York. Paperback.

9. KHOR, Martin. [Globalization and the South: Some Critical Issues], 2000. Spectrum Books: Ibadan. Paperback.

10. MORLEY, James. "Defining Postmodernism" N. P June 2012. Retrieved June 2013. Web.

11. NKWOKA, A. O. "Decolonizing Christian Religious Studies and Biblical Scholarship," [Rethinking the Humanities in Africa, SOLA Akinrinade et al Eds.], pp227-239, 2007. Obafemi Awolowo University Press: Ile-Ife. Paperback.

12. OLORUNTIMEHIN, B. Olatunji. "Rethinking Humanities Scholarship in Africa," [Rethinking the Humanities in Africa, SOLA Akinrinade et al Eds.], pp3-24, 2007. Obafemi Awolowo University Press: Ile-Ife. Paperback. 
13. KUNIN, D. Seth. "Introduction," [Theories of Religion: A Reader, KUNIN, D. Seth and JONATHAN, Miles- Watson Eds.], pp1-21, 2006. Rutgers University Press: New Jersey. Paperback.

14. SKORDILI, Beatrice. "Sociology," [Encyclopedia of Postmodernism, VICTOR E. Taylor and CHARLES E. Winquist Eds.], pp376-338, 2001. Routledge: London and New York. E-book. 